\title{
Designing Smart Student Savings Tools Based on Arduino and Web
}

\author{
${ }^{1}$ Sigit Pardjono ${ }^{*}{ }^{2}$ Asep Juarna \\ Universitas Gunadarma Jakarta
}

\begin{abstract}
Fresh In this modern era, everything is done easily, from electronic equipment to electronic transactions is developed increasingly sophisticated. The equipment and sophisticated electronic transactions turned out to have major problems that could result in dissipation, especially students in schools. The purpose of this study is to create and design a smart savings machine tool, where this machine will be controlled via RFID and a sensor with a microcontroller, so that each individual can learn to economize in managing finances. This machine is designed by adding a color sensor for depositing and withdrawing cash with only three nominal banknotes, namely Rp. 10,000, Rp. 5,000 and Rp. 2,000. Furthermore, this device is also able to calculate the financial balance that has been entered. As an input, Arduino Mega 2560 is needed for data processing. Whereas, the color sensor output is used to read the basic colors red, green and blue on the surface of the lower left corner of the rupiah banknotes. This tool works as desired, can read RFID (Radio Frequency Identification) cards that have been determined and the color sensor can respond to colors on a nominal bill of Rp 2,000, Rp.5,000 or Rp. 10,000 and able to detect the time when saving and accumulating the balance. To attract money into the storage area, two DC motors are used. When the TCS230 color sensor detects money, there are several times that the currency is unreadable due to the influence of external light which causes the sensor to be inaccurate in reading the frequency value of the money color.
\end{abstract}

Keywords: RFID, Color Sensor, Arduino Mega 2560

\section{Introduction}

The hallmark of modern times is that everything is made very easy, from electronic equipment to increasingly sophisticated electronic transactions. The sophisticated electronic equipment and transactions turned out to be a major problem that could result in dissipation for someone, especially students at school. There is no other because it is so easy to use two different tools but it is intended as a convenience provider without taking into account the costs incurred. The nature of dissipation like that is what every individual should be able to overcome even avoid it by applying frugality, especially in using money to transact in order to create a planning system in transacting their money properly. One way to save money is done by saving money on a machine that can be accessed by yourself. Hence, we need a tool that can manage income and finance. This tool is needed to save a number of banknotes easily.

\section{Mikrokontroler Arduino Mega 2560}

Arduino Mega 2560 is a microcontroller board with a type of chip made by ATMEL with type ATmega2560. The microcontroller has 54 digital input / output pins (15 can be used as PWM outputs), 16 analog inputs, 4 UART (hardware serial port), $16 \mathrm{MHz}$ crystal oscillator, USB connection, power jack, ICSP header, and reset button. The microcontroller is built as well as possible because it contains everything needed to support the microcontroller. it requires low power consumption, just powered by connecting it to the computer with a USB cable or turn it on with an AC-to-DC adapter or a battery to be used. 


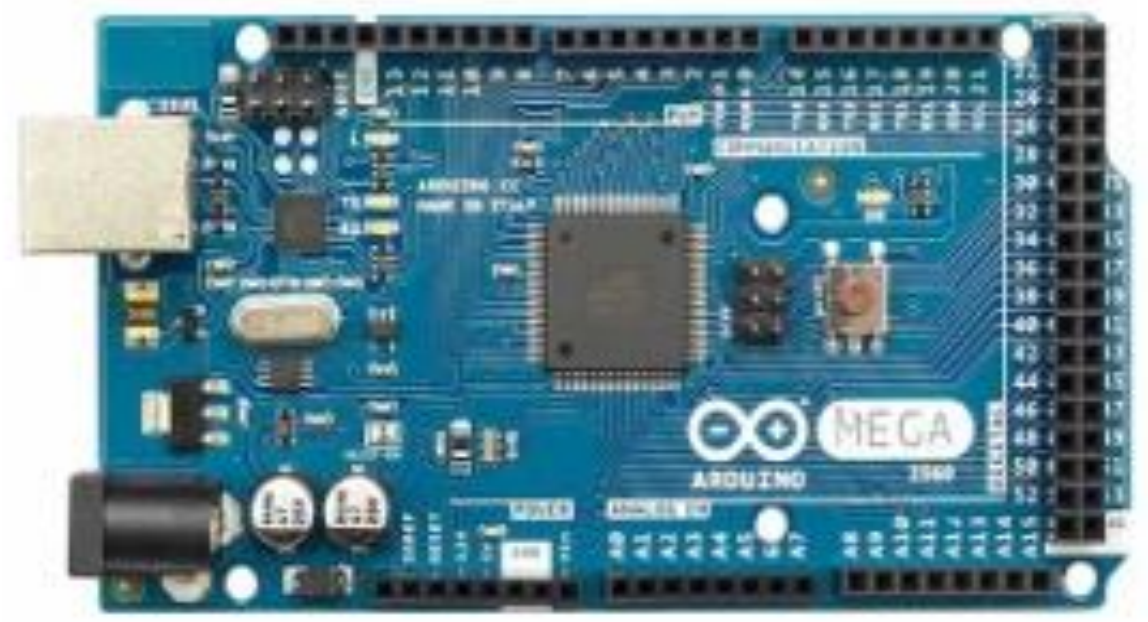

Figure 1: Board of Arduino Mega 2560

(http://ecadio.com/image/catalog/information/belajar-arduino-mega-2560.jpg)

Arduino Mega 2560 Rev 3 has been equipped with ATmega16U2 chip which has been programmed as a USB to Serial converter. Also equipped with a polyfuse that can be reset to protect the USB port of your computer / laptop from short circuit or overcurrent. The ATmega2560 chip has $256 \mathrm{~KB}$ of memory, with 8 $\mathrm{KB}$ of that memory already being used for the bootloader. $8 \mathrm{~KB}$ SRAM, and 4 KB EEPROM, which can be read and write using the EEPROM library when programming.

\section{Pin Configuration on ATMega2560}

The pin configuration on the ATMega2560 is shown in Figure 2. ATMega2560 has as many as 54 pins. These pins have their respective functions. Some function as power pins, as digital input and output pins and analog input pins.

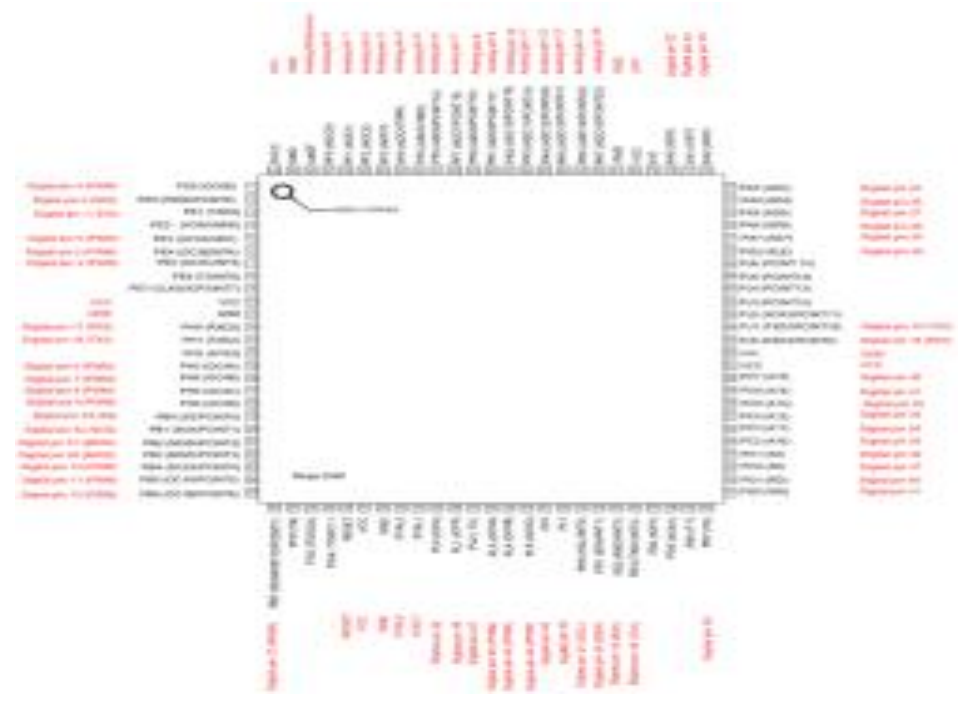

Figure 2: Pin Configuration on ATMega2560

\section{Liquid Crystal Display (LCD)}

LCD or liquid crystal screen is a device for displaying text or numbers. LCD is a popular display device that is used in many ways such as amateur radio, pocket calculators, and mini TVs. Most LCDs are configured as a seven-segment display to allow display of alpha numeric and limited characters. The LCD suppresses reflections or lights in the LCD segment. This results in a dark area in the LCD segment. So, the LCD screen cannot be used in the dark or low light levels. 


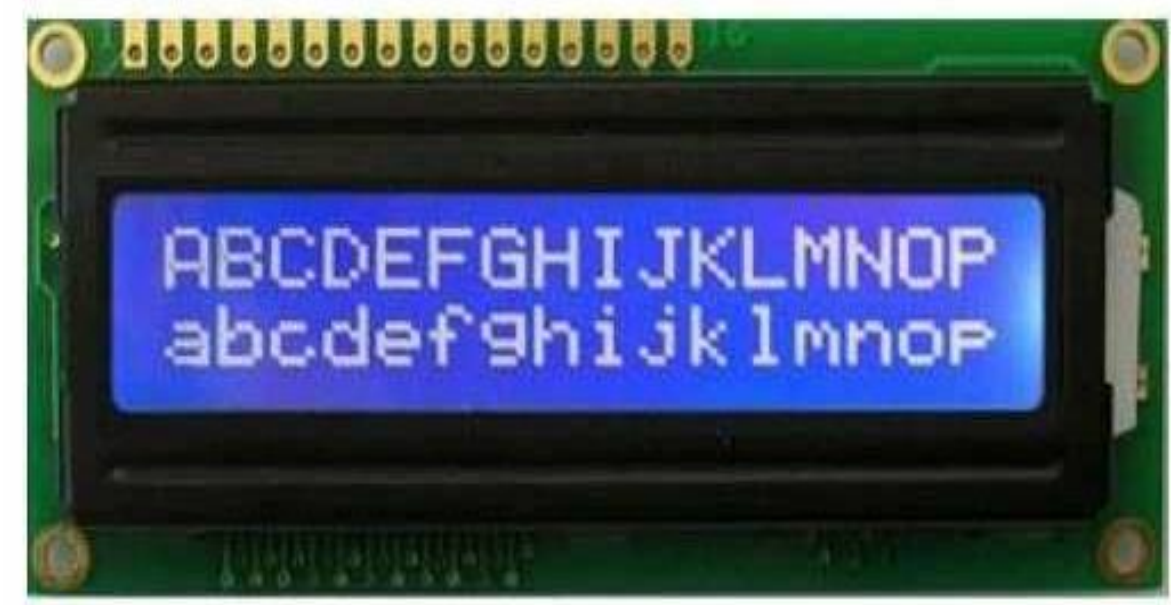

Figure 3: LCD $2 x 16$

(https://www.robotistan.com/2x16-lcd-screen-white-over-blue-tc1602a-2619-11-B.jpg)

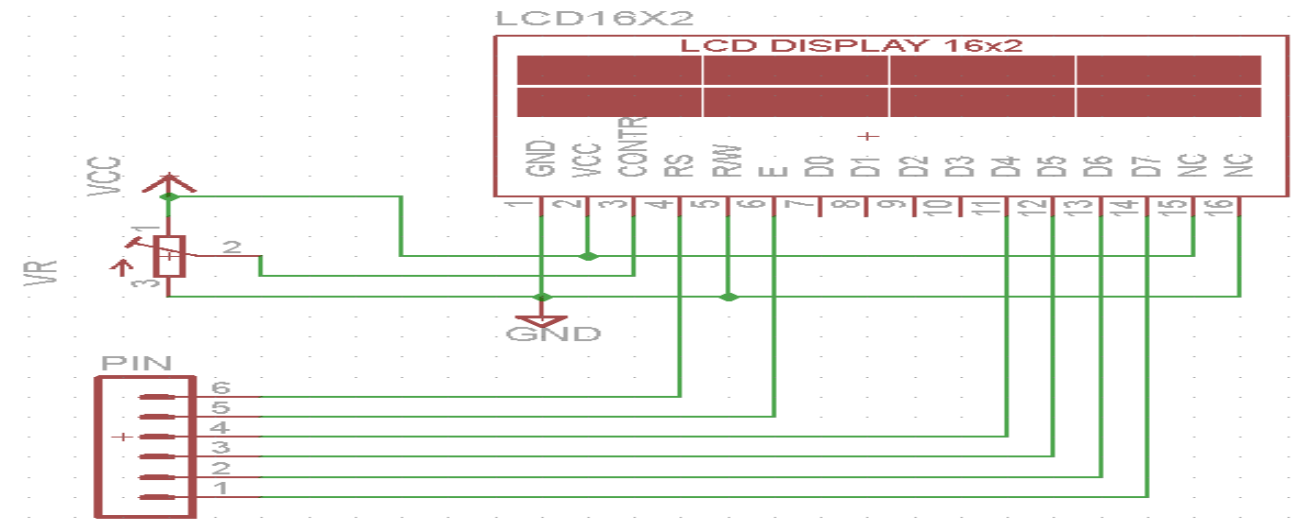

Figure 4: LCD Configuration $2 \times 16$

(https://www.robotistan.com/2x16-lcd-screen-white-over-blue-tc1602a-2619-11-B.jpg)

\section{Radio Frequency Identification}

RFID is an identification system that enables data retrieval without having to touch such as barcodes and magnetic cards. RFID is able to transmit identity in the form of certain digits using radio waves and identification systems with radio waves. To operate it requires two devices, namely the so-called Tag and Reader. When scanning data, the Reader reads the signal emitted by the Radio Frequency (RF) signal given by the RFID Tag.

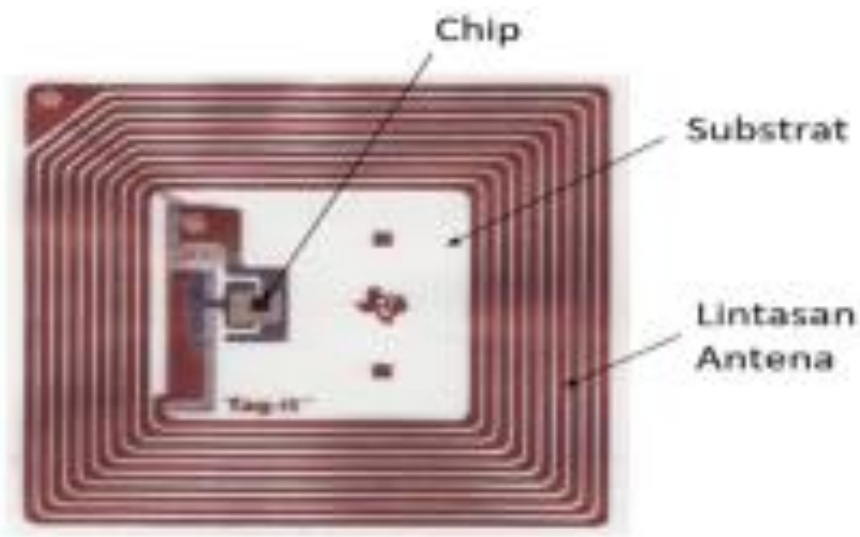

RFID TAG

Figure 5: Part of Tag on RFID

(http://3.bp.blogspot.com/-enQcKT5gy10/VP68Ppxj1mI/AAAAAAAAATc/ziENUK3ZSsQ/s1600/RFIDchip.png) 


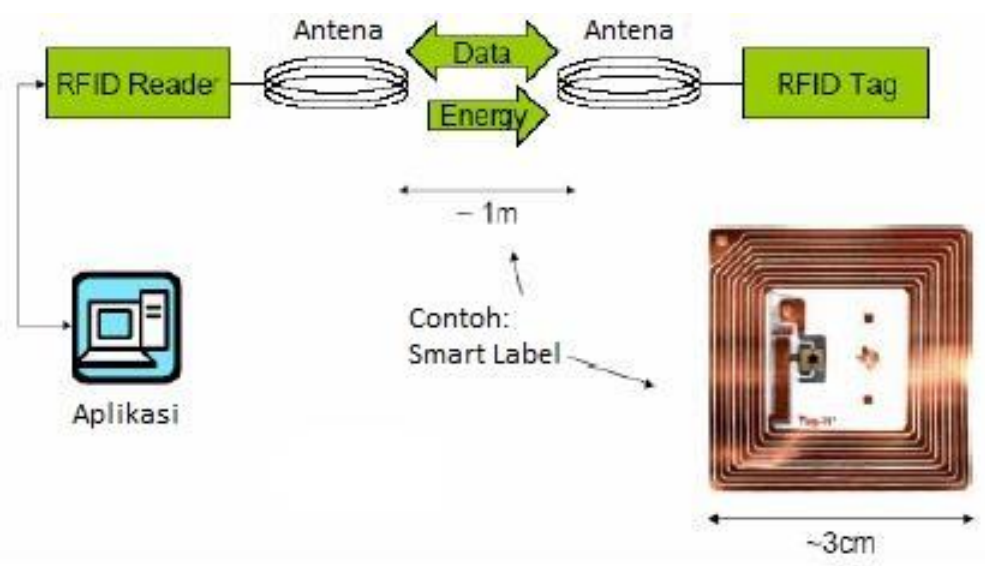

Figure 6: Work scheme of RFID

(http://oipall.blog.st3telkom.ac.id/wp-content/uploads/sites/302/2016/01/Komponen-Utama-dalam-SistemRFID.jpg)

\section{Motor DC}

DC motors are electric motors that require a direct current voltage supply in the field coil to be converted into mechanical motion energy. The field coil on the dc motor is called the stator (the part that is not rotating) and the anchor coil is called the rotor (the rotating part). Direct current motors, as the name suggests, use direct current that is not direct / direct-unidirectional. The main advantage of a DC motor is that it controls the speed, which does not affect the quality of the power supply.

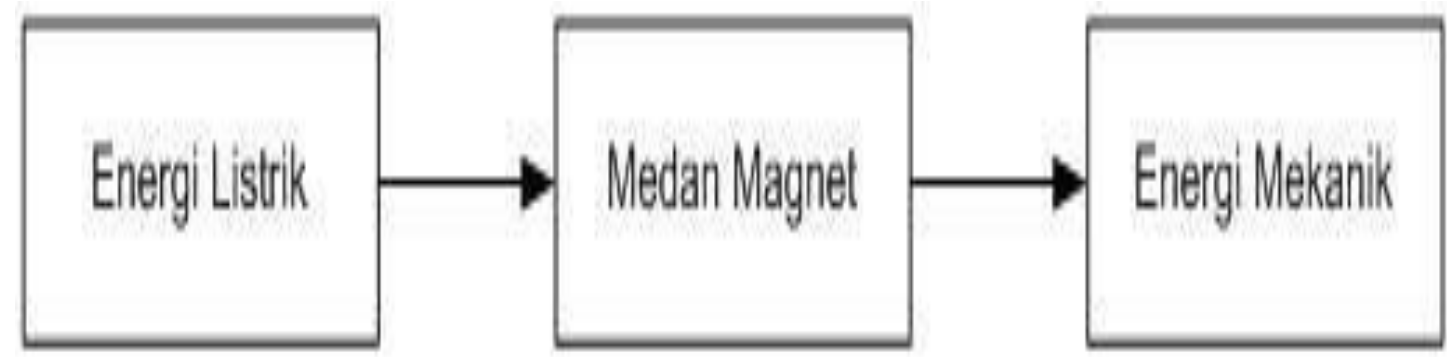

Figure 7: DC Motor Working Principle

\section{TCS230 Color Sensor}

TCS230 color sensor is a color sensor that is often used in microcontroller applications for the detection of an object or the color of the object being monitored. The TCS230 color sensor can also be used as a motion sensor, where the sensor detects the movement of an object based on the color changes received by the sensor. Basically, the TCS230 color sensor is a series of photodiodes arranged in an 8x8 matrix array with 16 photodiode configurations that function as red filters, 16 photodiodes as blue filters and 16 photodiodes again without color filters. TCS230 color sensor is a sensor that is packaged in an 8 pin DIP chip with a transparent face as a place to receive colored light intensity.

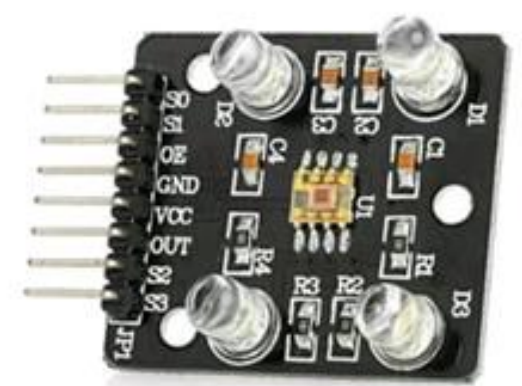

Figure 8: (a) Physical form of sensor TCS230

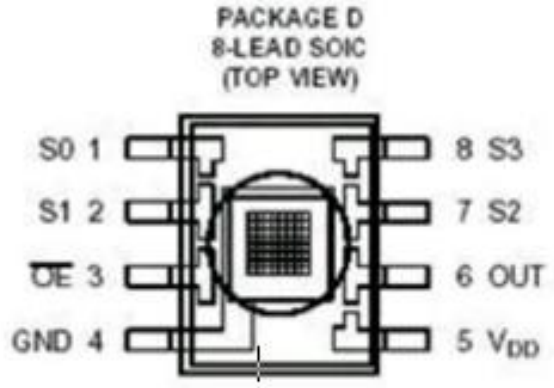

(b) Sensor pin scheme TCS230 


\section{Keypad}

Keypad is one type of interface device commonly found on microcontroller systems, it is a $4 \times 4$ or $3 \times 4$ matrix keypad. As a consequence, as long as no buttons are pressed, the microcontroller will see as logic high "1" on each pin connected to the line.
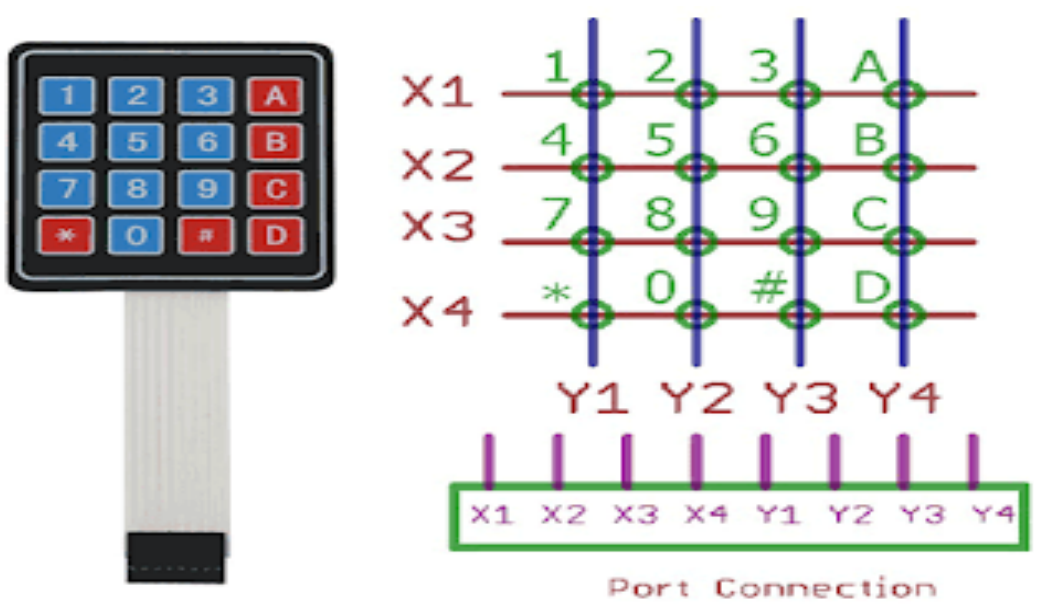

Figure 9: Matrix 4x4 keypad (Tri Rahajoeningroem \& Wahyudi, 2013)

\section{NodeMCU ESP8266}

NodeMCU is an open source IoT platform and development kit that uses the Lua programming language to assist in making prototypes of IoT products or can be sketched with an adruino IDE. The development of this kit is based on the ESP8266 module, which integrates GPIO, PWM (Pulse Width Modulation), IIC, 1Wire and ADC (Analog to Digital Converter) all on one board.

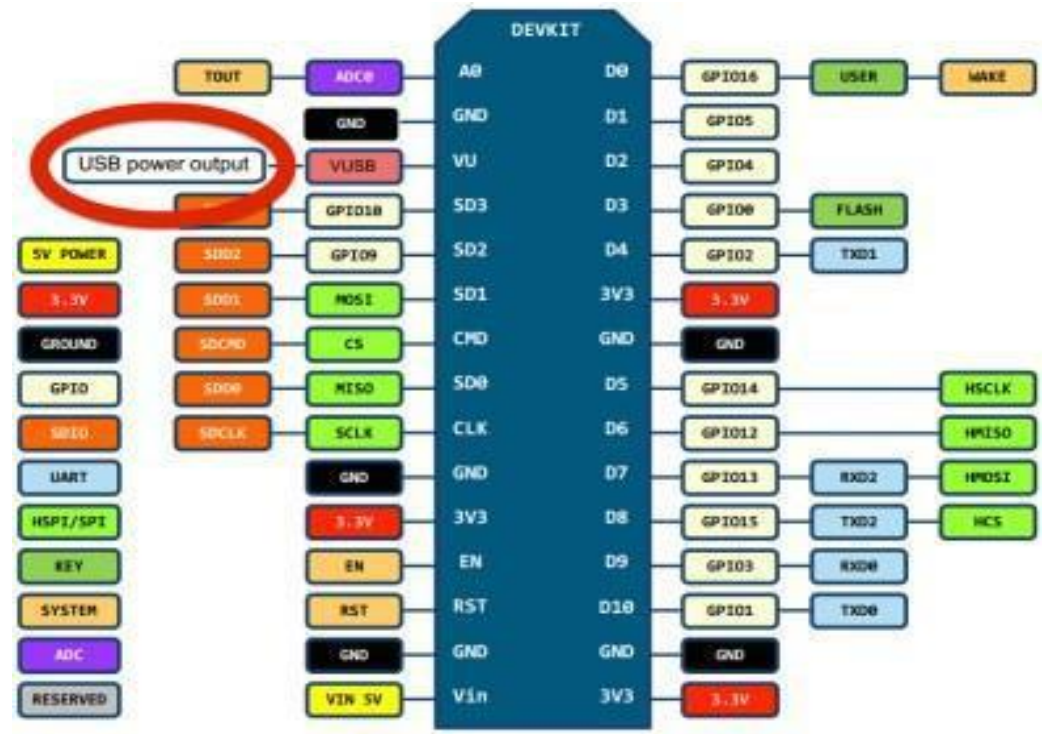

\section{Figure 10: GPIO NodeMCU ESP8266 v3}

\section{Research Methodology}

Based on the research method used, the initial stage in developing this tool is planning, preparing all the needs in making tools in the form of paper writing material, electronic components and software used in making the program. Then in the next stage is analyzing by observing, researching, collecting and analyzing everything related to research. All tools that have been designed will then be done making the program. Programming is done using the Arduino $\mathrm{C}$ programming language, HTML, PHP. 


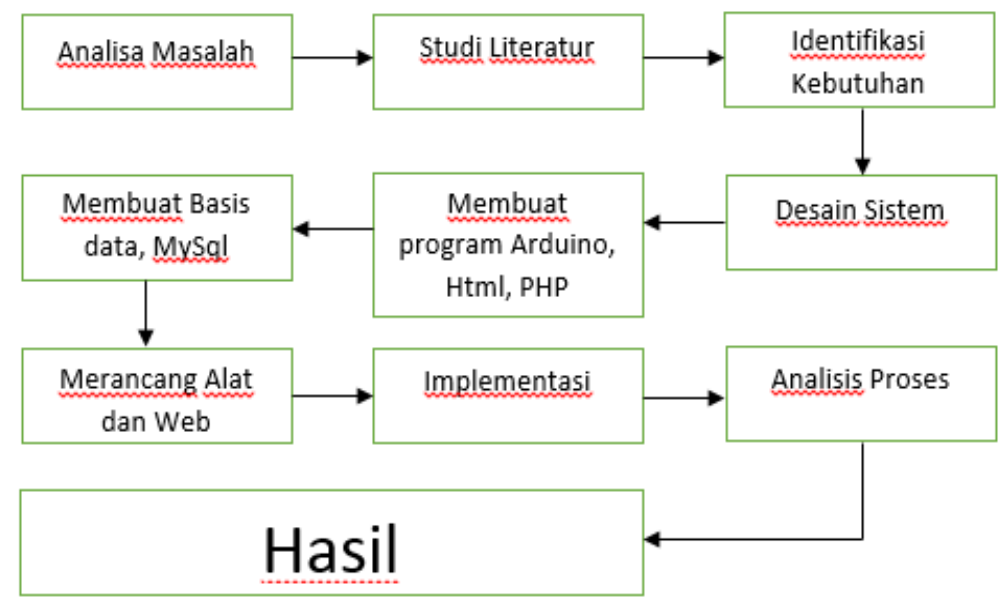

Figure 11: Research Framework

\section{Finding and Discussion}

\section{Block diagram analysis}

Block diagram analysis presents an overview of how the student savings system works.

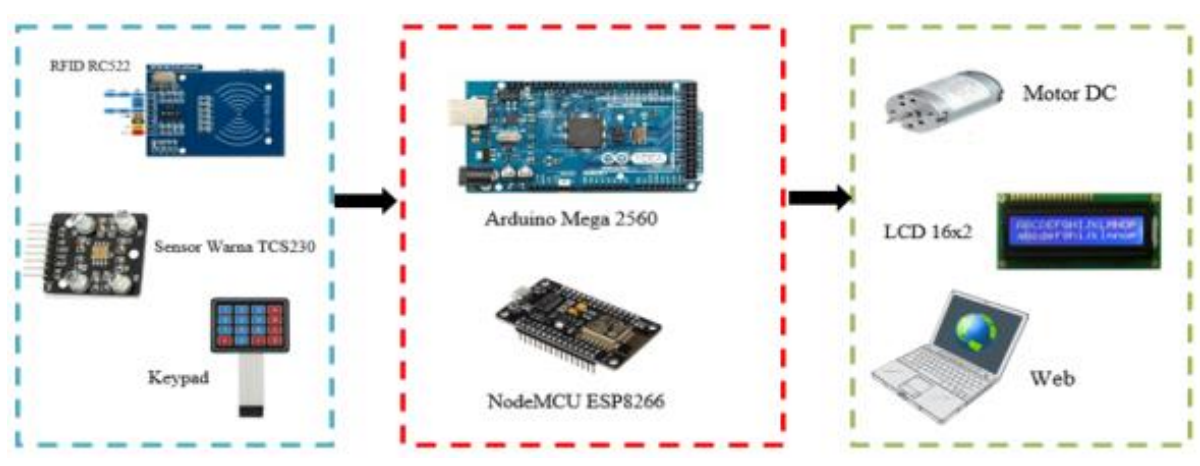

Figure 12: Diagram Block

In the block diagram above, it can be seen that there is an RC522 RFID as a tap card reader. The RFID Card has been programmed to contain the student's personal identity such as account number, full name, full address, gender after the card is tapped, the student / client enters the password via the keypad when the password entered correctly then the LCD will display the message "Password Match, Access Granted" if you enter the wrong password, then the message "Wrong Card Please try Again" will be displayed and make sure the password is not entered incorrectly. The next step is to place banknotes in Rp.2,000, Rp.5,000, or Rp.10,000 denominations and place them on the TCS230 color sensor that will read the RGB color based on the currency.

In the next step the TCS230 color sensor will read the colors on the money and the LCD will display the message "Nominal Identification" when it has been read by the sensor. The LCD will display the message "Nominal Money" according to the currency placed on the TCS230 color sensor bag, after that the DC motor will withdraw the money into a box with a rotation duration of 3 seconds after the money enters the LCD lunch box will display the message "Finish Thank You", The next step is NodeMCU ESP8266 which integrates the ADC (Analog to Digital Converter) with the serial Wifi feature connected by the laptop that is connected to the laptop. enter the Web which will display the amount of money entered as read by the color sensor. In the web view, identity, money in and the time when students / clients save will appear and students can see the total money that came in by looking at the account code that can be accessed by the admin.

\section{Tool Design}

The concept of a smart savings monitoring system based on Arduino students and the web uses two stages, namely the design of the physical form of the tools and the design of the Software. 


\section{Tool Schema}

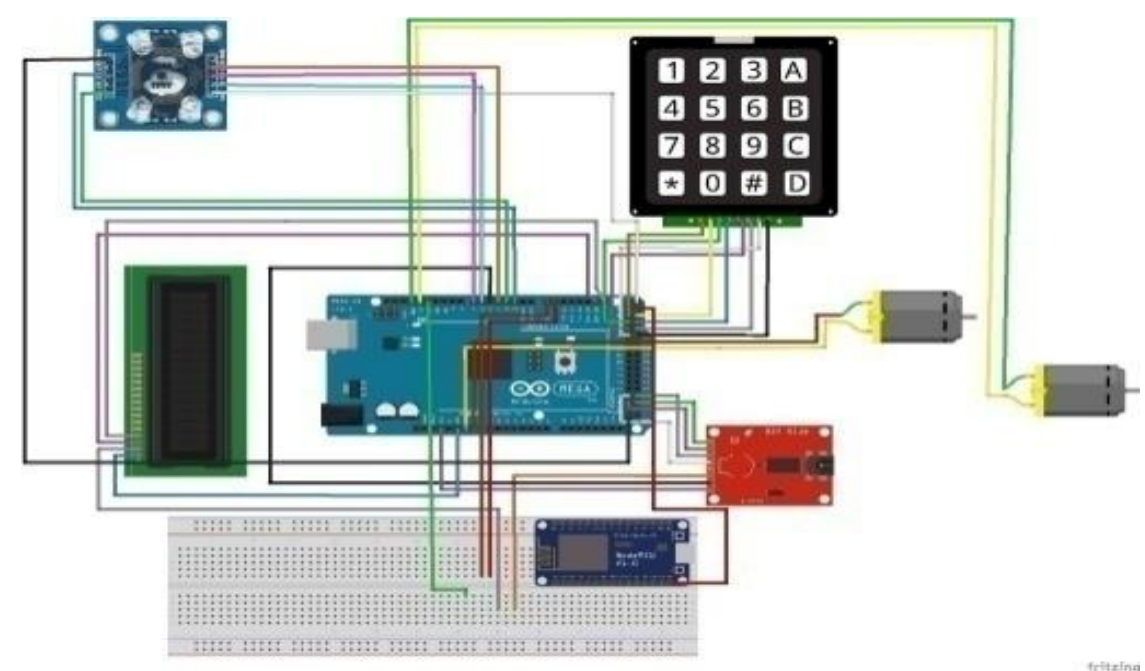

Figure 13: Tool Schema

\section{Flowchart}

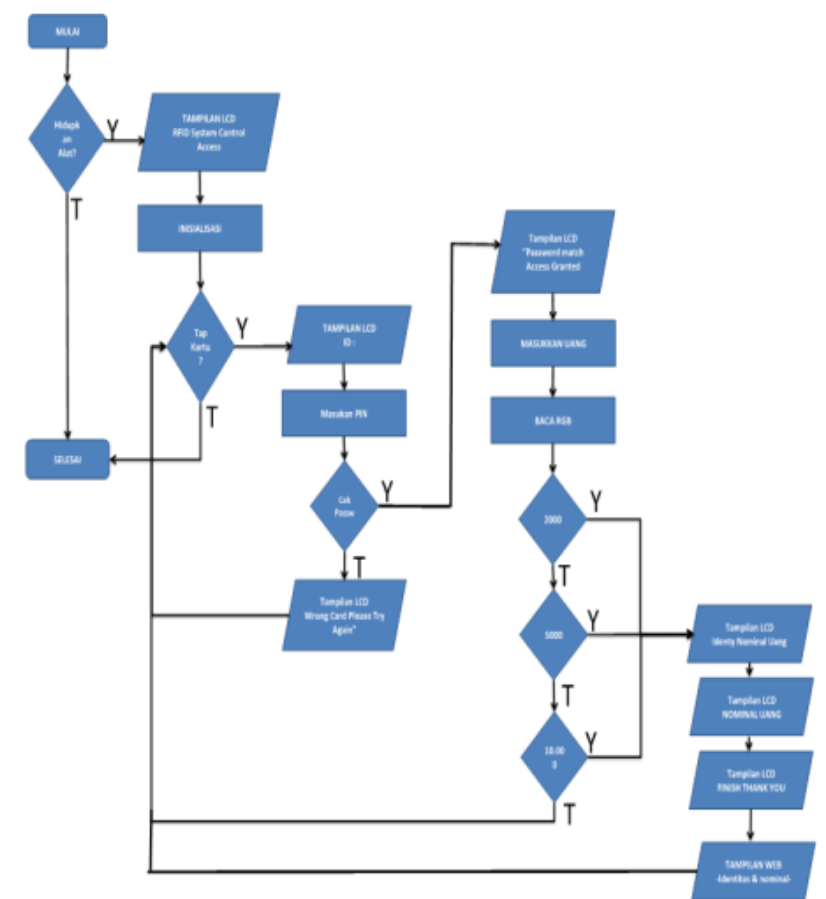

Figure 14: Flowchart

Based on Figure flowchat can be translated into a program that starts from the initial process or starts to turn the power ON button. The savings system will be active, when the device is on, the device will initialise after that the tool can be used by tapping the card into the RFID reader and then the LCD screen will appear on the user's ID by entering a PIN consisting of 4 letters, if you enter a wrong password then users re-tag the card and make sure the password is not incorrect. If the password is correct, the next step is to enter banknotes between Rp. 2,000, Rp. 5,000 and Rp. 10,000, then the color sensor will read the RGB of each coin, then the LCD display will identify the nominal value of the money after the display will appear on the LCD. total incoming cash that has been read by the sensor, the next ESP8266 will send data to the Web on its display will provide student identity information and the amount of money saved and displays the time when saving. In the web view can be seen in total from students while saving in full.

\section{Test Results on the RGB Color Sensor}

The sensor used is the TC230 Color Sensor This component can be used to measure RGB color parameters. 
Table 1: Testing the measurement of the color parameters of banknotes

\begin{tabular}{|c|c|c|}
\hline Banknotes & Pembacaan Nilai Warna & Output Sensor \\
\hline \multirow{3}{*}{ Rp.2000 } & Red & $50-65$ \\
\hline & Green & $60-70$ \\
\hline & Blue & $35-50$ \\
\hline \multirow{3}{*}{ Rp.5000 } & Red & $40-55$ \\
\hline & Green & $60-80$ \\
\hline & Blue & $50-65$ \\
\hline \multirow{3}{*}{ Rp.10.000 } & Red & $70-85$ \\
\hline & Green & $70-85$ \\
\hline & Blue & $35-45$ \\
\hline
\end{tabular}

In this experiment the TCS230 color sensor detects the color of the paper currency using a test table displaying measurement parameters on the serial plotter that is available in the Arduino software.

\section{Color Calibration Test Results}

The Arduino Mega 2560 microcontroller detects the color sensor it receives from the TCS230 color sensor circuit. Each of the red, green and blue colors gives a calibration value for each object it detects

Table 2: Testing Banknote Color Calibration Measurement on Rp. 2000

\begin{tabular}{|c|c|c|c|c|c|}
\hline \multirow{3}{*}{ Percobaan ke- } & \multirow{3}{*}{ Uang Kertas } & \multicolumn{3}{|l|}{ Parameter } & \multirow{3}{*}{ Ket. } \\
\hline & & \multirow{2}{*}{ Merah (R) } & \multirow{2}{*}{ Hijau (G) } & Biru & \\
\hline & & & & (B) & \\
\hline 1 & \multirow{10}{*}{ Rp.2000 } & 61 & 67 & 38 & Terbaca \\
\hline 2 & & 61 & 67 & 40 & Terbaca \\
\hline 3 & & 61 & 69 & 40 & Terbaca \\
\hline 4 & & 61 & 65 & 40 & Terbaca \\
\hline 5 & & 62 & 67 & 47 & Terbaca \\
\hline 6 & & 64 & 67 & 42 & Terbaca \\
\hline 7 & & 58 & 66 & 39 & Terbaca \\
\hline 8 & & 62 & 64 & 44 & Terbaca \\
\hline 9 & & 60 & 62 & 44 & Terbaca \\
\hline 10 & & 67 & 62 & 46 & Terbaca \\
\hline
\end{tabular}


Tabel 3: Testing Banknote Color Calibration Measurement on Rp. 5000

\begin{tabular}{|c|c|c|c|c|c|}
\hline \multirow{3}{*}{ Percobaan ke- } & & & ameter & & \\
\hline & \multirow{2}{*}{ Uang Kertas } & \multirow{2}{*}{$\operatorname{Merah}(\mathbf{R})$} & \multirow{2}{*}{ Hijau (G) } & Biru & \multirow{2}{*}{ Ket. } \\
\hline & & & & (B) & \\
\hline 1 & \multirow{10}{*}{ Rp.5000 } & 43 & 66 & 54 & Terbaca \\
\hline 2 & & 43 & 66 & 57 & Terbaca \\
\hline 3 & & 43 & 72 & 63 & Terbaca \\
\hline 4 & & 43 & 75 & 63 & Terbaca \\
\hline 5 & & 50 & 73 & 60 & Terbaca \\
\hline 6 & & 53 & 69 & 55 & Terbaca \\
\hline 7 & & 44 & 69 & 58 & Terbaca \\
\hline 8 & & 45 & 70 & 52 & Terbaca \\
\hline 9 & & 48 & 72 & 61 & Terbaca \\
\hline 10 & & 48 & 72 & 64 & Terbaca \\
\hline
\end{tabular}

Tabel 4: Testing Banknote Color Calibration Measurement on Rp. 10.000

\begin{tabular}{|c|c|c|c|c|c|}
\hline \multirow{3}{*}{ Percobaan ke- } & \multirow{3}{*}{ Uang Kertas } & \multicolumn{3}{|l|}{ Parameter } & \multirow{3}{*}{ Ket. } \\
\hline & & \multirow{2}{*}{$\operatorname{Merah}(\mathbf{R})$} & \multirow{2}{*}{ Hijau (G) } & Biru & \\
\hline & & & & (B) & \\
\hline 1 & \multirow{10}{*}{ Rp.10.000 } & 77 & 71 & 38 & Terbaca \\
\hline 2 & & 75 & 80 & 38 & Terbaca \\
\hline 3 & & 75 & 83 & 40 & Terbaca \\
\hline 4 & & 82 & 77 & 44 & Terbaca \\
\hline 5 & & 80 & 75 & 42 & Terbaca \\
\hline 6 & & 75 & 73 & 35 & Terbaca \\
\hline 7 & & 79 & 79 & 39 & Terbaca \\
\hline 8 & & 82 & 72 & 41 & Terbaca \\
\hline 9 & & 80 & 77 & 40 & Terbaca \\
\hline 10 & & 80 & 73 & 37 & Terbaca \\
\hline
\end{tabular}

\section{Test Results on RFID}

RFID uses a radio wave identification system. For this reason, at least two devices are needed, namely the so-called TAG and READER. When scanning data, READER reads the signal given by RFID TAG. 


\begin{tabular}{|l|l|}
\hline PinRFID & Pin Arduino \\
\hline VCC & VCC 5 Volt \\
\hline GND & Ground \\
\hline RST & 3 \\
\hline SS (SDA) & 4 \\
\hline MOSI & ICSP-4 \\
\hline MISO & ICSP-1 \\
\hline SCK & ICSP-3 \\
\hline
\end{tabular}

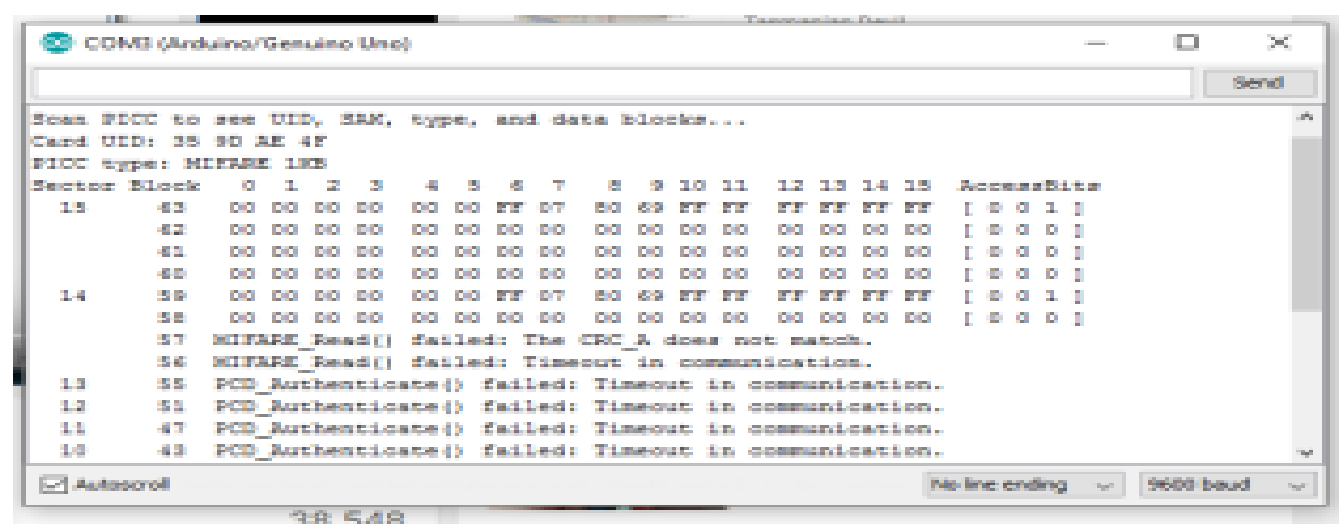

Figure 15: Trial Card Readings on RFID Reader

Table 6: RFID test results

\begin{tabular}{|l|c|c|c|}
\hline Test & Distance (CM) & Front Look & Backview \\
\hline 1 & 0 & Legible & Legible \\
\hline 2 & 1 & Legible & Legible \\
\hline 3 & 2 & Legible & Legible \\
\hline 4 & 3 & Legible & Legible \\
\hline 5 & 4 & Legible & Illegible \\
\hline 6 & 5 & Illegible & Illegible \\
\hline 7 & 6 & Illegible & Illegible \\
\hline 8 & 8 & Illegible & Illegible \\
\hline 9 & 9 & Illegible & Illegible \\
\hline 10 & \multicolumn{2}{|c|}{ Illegible } & Illegible \\
\hline
\end{tabular}

Based on testing of RFID cards those are closer to a certain distance, the results obtained that RFID can read cards or tags around $0 \mathrm{~cm}$ to $4 \mathrm{~cm}$.

\section{Tool Testing}

This time the test was conducted to find out whether the entire system can run well and function as expected. 


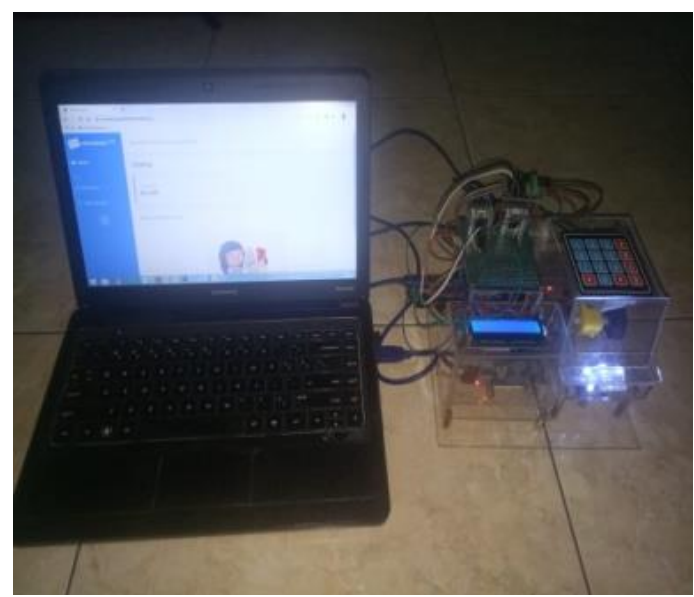

Figure 16: Tool Design Scheme

In testing this tool is done by providing a voltage so that the tool can be operated. Experiments in this series will produce an output that will be displayed via web media. The output will be generated from the TCS230 sensor which reads the color frequency. Then the data will be sent automatically to the web server and then appear even though it is safe on the web and notifies the amount of money saved and notifies the final balance on the web, thus students who save can see the balance of the balance and the time when saving transactions.

\section{Overall Device Testing}

Testing is done when students start making savings transactions on the tool and can monitor the amount of balance and currency in the savings and get results on the web in the form of displays on web pages and data stored in the database.

The test is carried out with the following steps:

1. Giving a DC power supply voltage (voltage) to the appliance using an adapter with 12 Volt power.

2. After connecting to a series of devices, the RFID, TC230 color sensor, 4x4 keypad, Aduino Mega, ESP8266, DC motor and LCD will be active and enter into the Web display on the laptop.

3. When all components are active and the web page is ready, the transaction process can be done with students having an RFID Card as an account that is already registered and can make a savings process with paper currency denominations with a nominal Rp.2,000, Rp. 5,000, Rp. 10,000

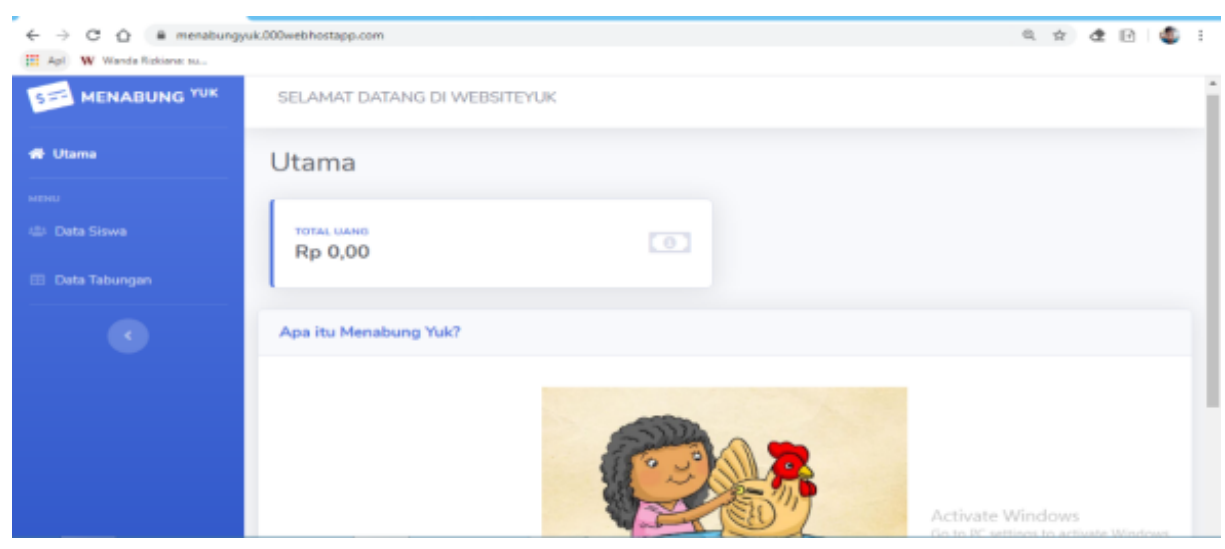

Figure 17: Main Page Display

1. Ensure that students are registered in the database and registered on the web with the Add Student menu and have an RFID card containing an ID and PIN consisting of four digits for student access to savings. 


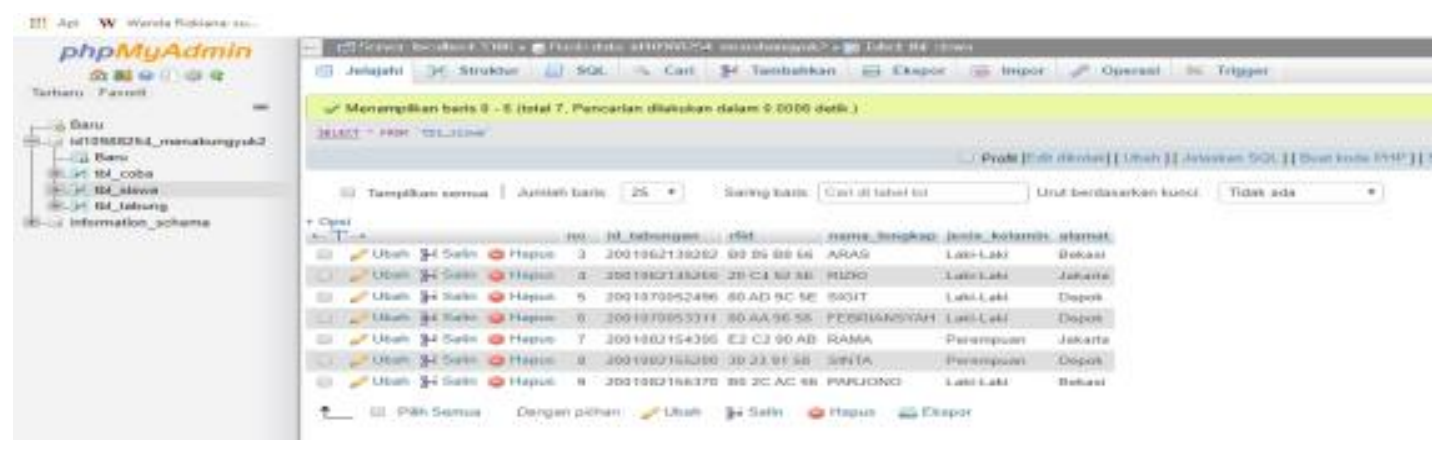

Figure 18: Display of Students Database

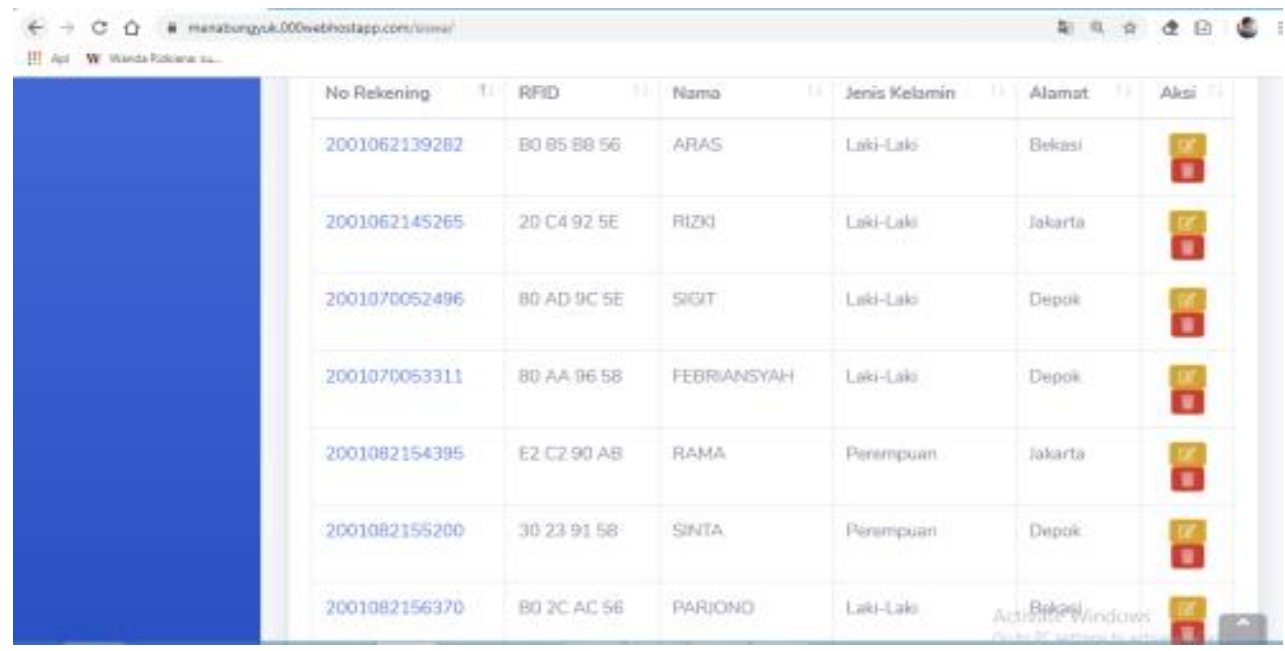

Figure 19: Display of Srudents' data on the Web

2. After having an account, students can make transactions with banknotes, with the first attempt using Rp.10,000 by taping an RFID card and entering the PIN that has been registered, then entering Rp.10,000 in money and placed in the TCS230 color sensor position.

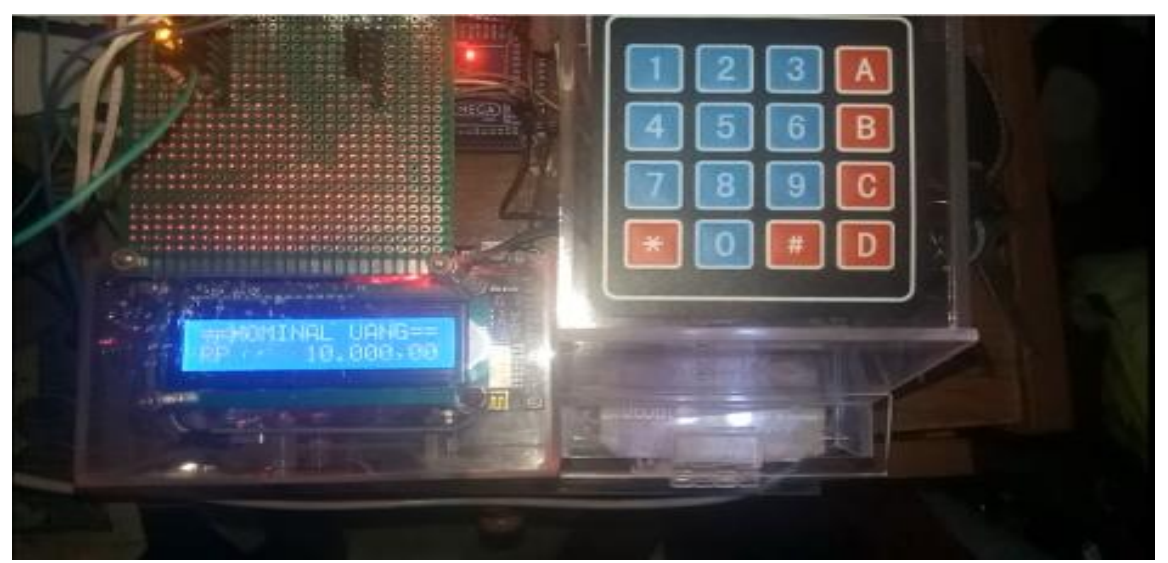

Figure 20: LCD display when the color sensor reads RGB at Rp.10,000 
3. Then Arduino will send data to the Web with ESP8266 already connected by the internet.

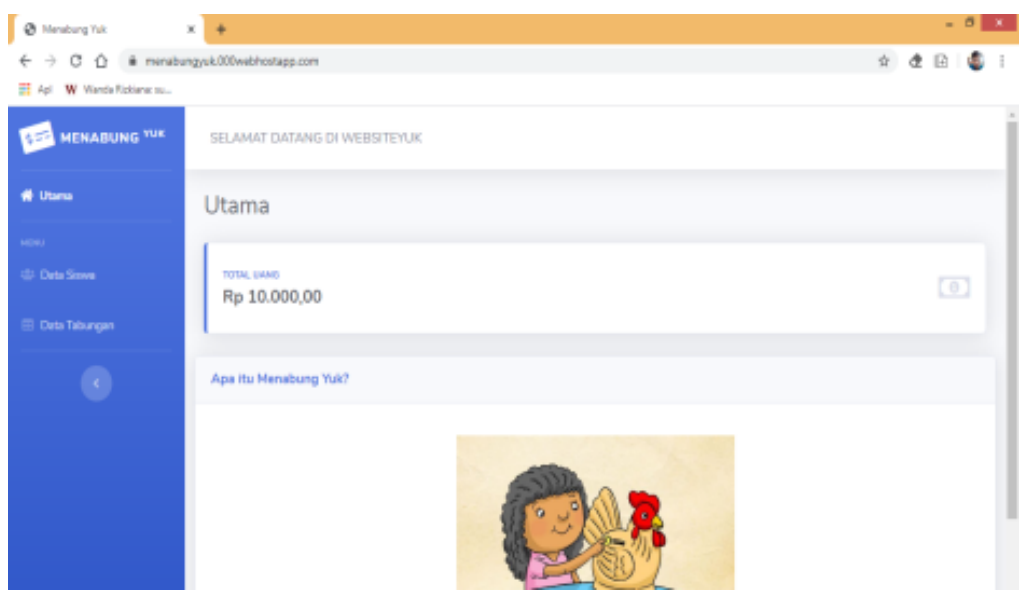

Figure 21: Arduino Sends Data to the Web at Rp.10,000

4. Then enter the Savings Data menu, then students can monitor the results of saving transactions with information in the form of Account No., RFID, Full Name, Amount and Time.

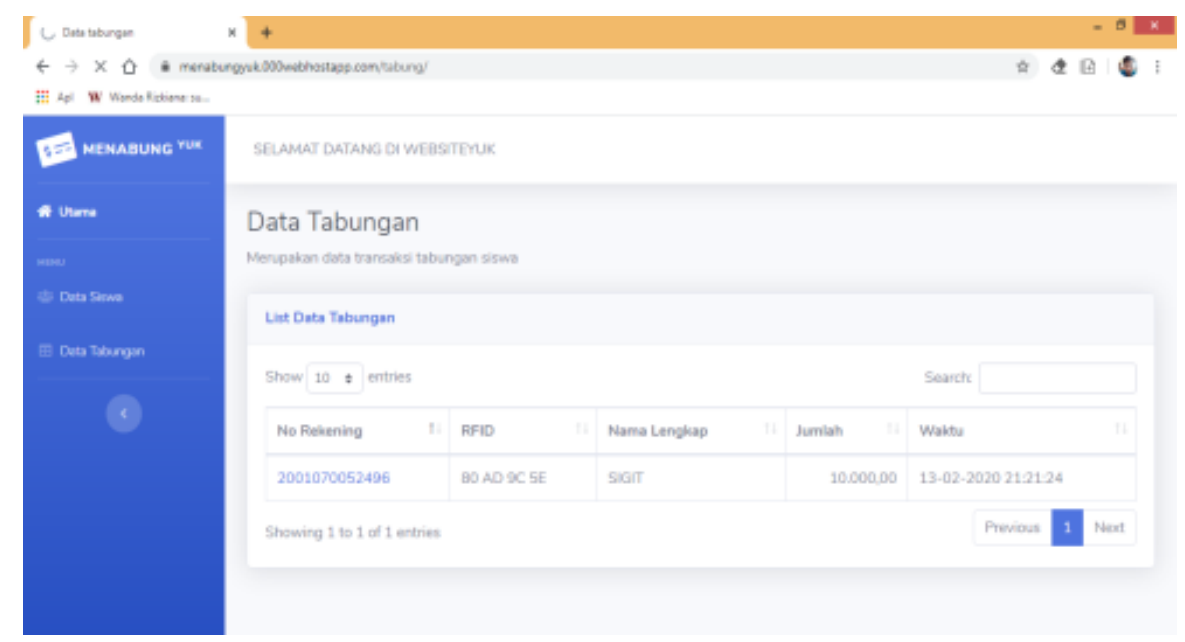

Figure 22: Display Savings Data with a nominal Rp.10,000

5. Then with the second experiment using Rp.2,000

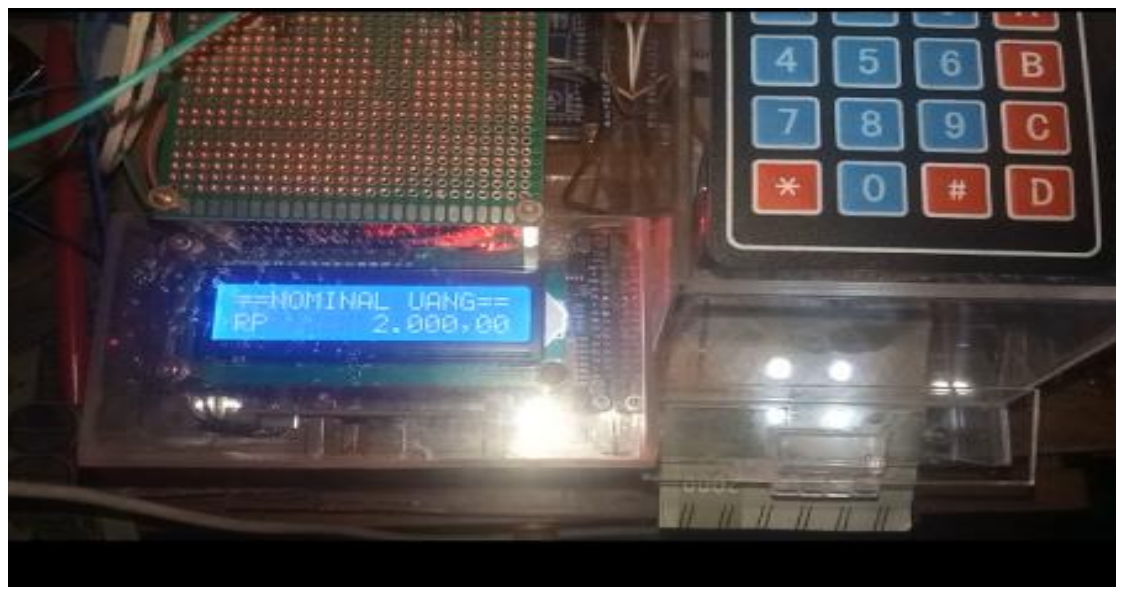

Figure 23 LCD display when the color sensor reads RGB at Rp. 2,000 
6. After Arduino sends data to the Web, the main display balance will change to a total nominal of Rp. 12,000 because students save with a currency of Rp. 2,000.

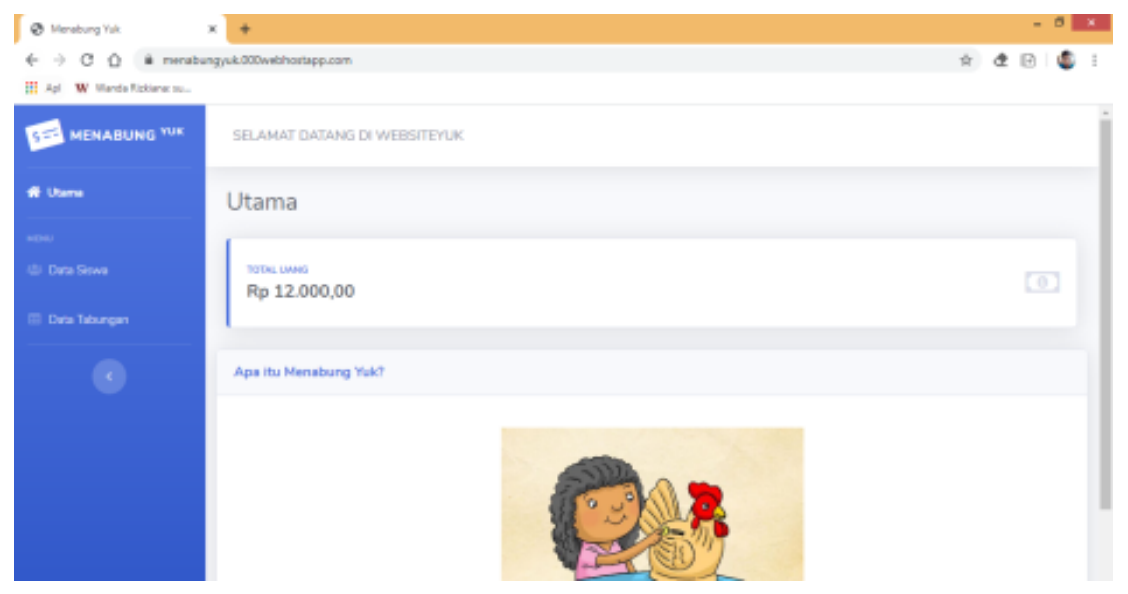

Figure 24: Increased balance by saving Rp.2,000

7. Then students can monitor savings balances by looking at the Savings Data menu

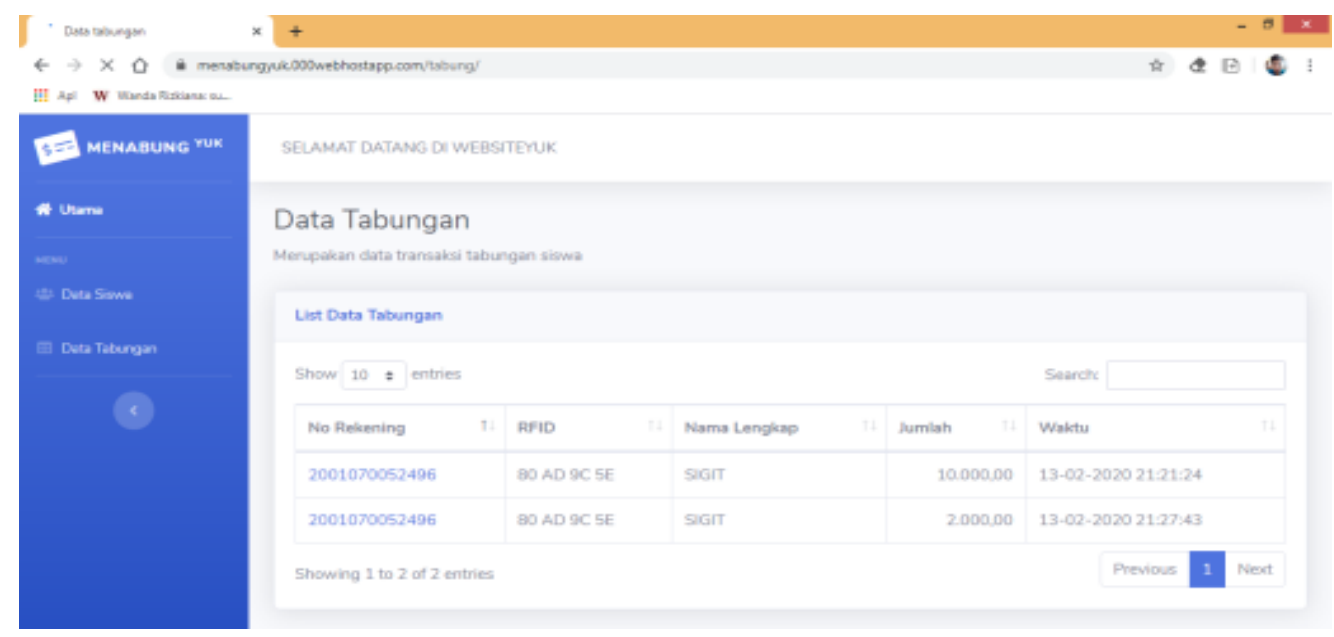

Figure 25: Display Savings With Nominal Rp.2,000

8. Then with the third experiment using money Rp.5,000

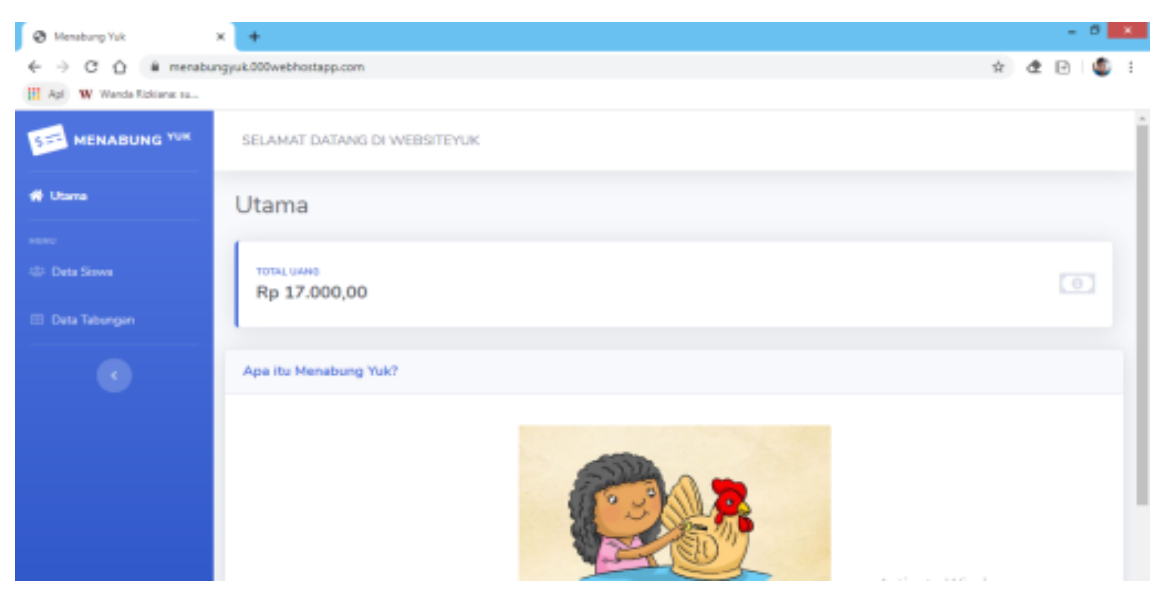

Figure 26: LCD display when the color sensor reads $R G B$ at $R p .5,000$

9. After Arduino sends data to the Web, the main display balance will change to a total nominal of Rp. 17,000 because students save with a currency of Rp. 5,000, when each student saves then the web 
display will automatically change according to the amount of money that goes into the tool smart savings even though all students save in one machine and can monitor savings by entering menu on Account number,

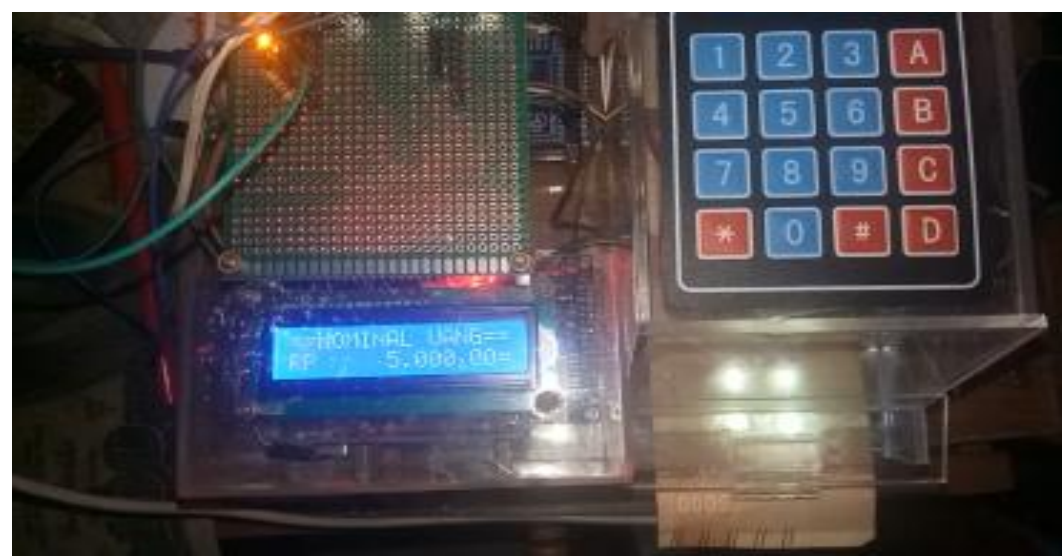

Figure 27: Increased balance by saving IDR 5,000

10. Then, students can monitor savings balances by looking at the Savings Data menu

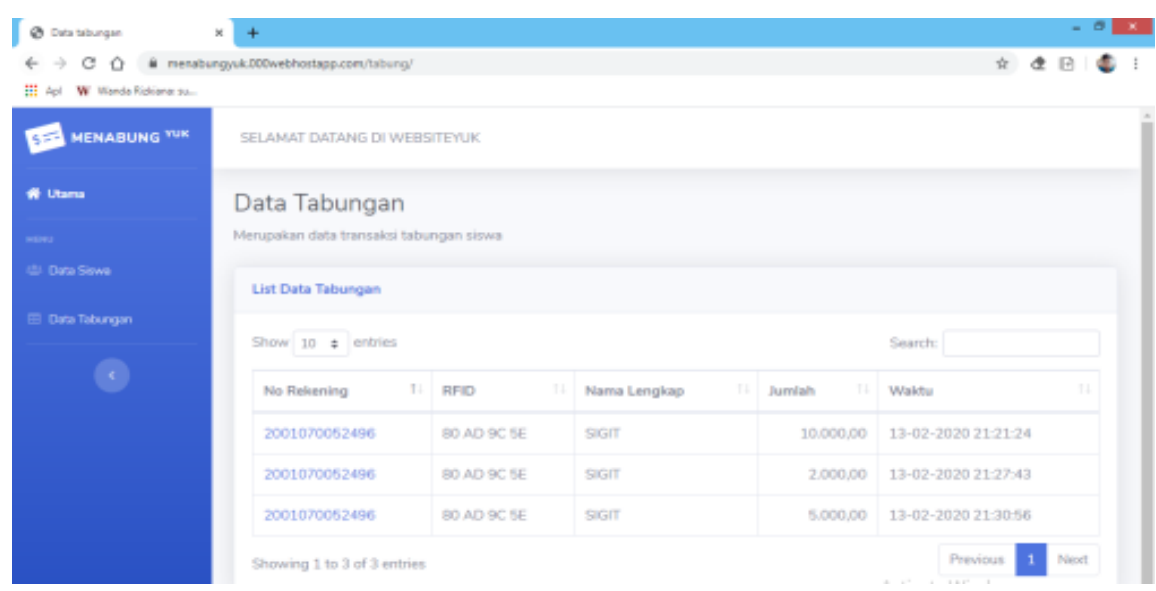

Figure 28: Display Savings with a nominal Rp.5,000

11. If students want to see the total from the beginning of saving by clicking the respective account number listed on the savings data menu.

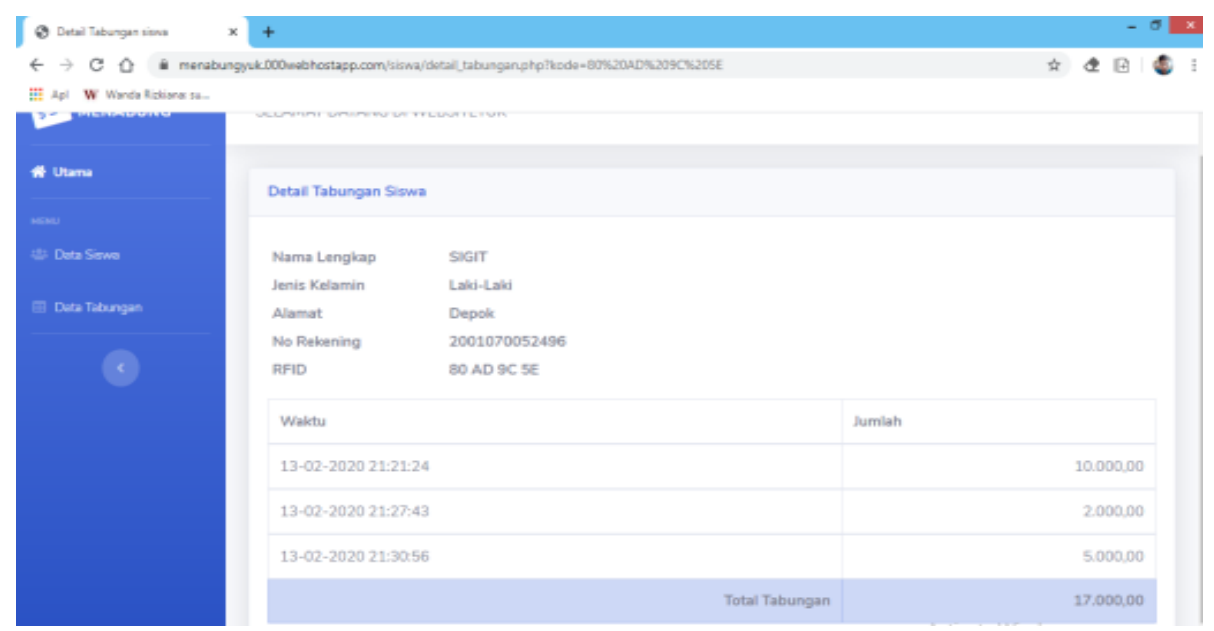

Figure 29: The Detail on Display of Student Savings 


\section{Conclusion}

Based on the results of this study, the authors get several conclusions, namely:

a. This tool works as desired, can read RFID (Radio Frequency Identification) cards that have been determined and the color sensor can respond to colors on a nominal bill of Rp 2,000, Rp.5,000 or Rp. 10,000 and can see the time when saving and accumulating the balance.

b. To attract money into the storage area, two DC motors are used.

c. hen the TCS230 color sensor detects money, there are several times that the currency is unreadable due to the influence of external light which causes the sensor to be inaccurate in reading the frequency value of the money color.

\section{Suggestions}

There are still shortcomings on this tools. Hence, a few inputs to improve the Smart Savings Tool for Arduino and Web-Based Students in the future better. Some suggestions are proposed including the following points:

a. The development of this tool is expected to reduce the unreadability of currencies by using more effective sensors to be accurate in reading RGB values.

b. This tool can be developed by adding cameras or size sensors and other sensors such as money authenticity sensors. So that this classification process can be more precise in determining the authenticity of money and nominal money according to this tool.

\section{Refferences}

[1.] Arduino.-Arduino- Arduino Board Mega 2560\|. Retrieved from http://www.arduino.cc/en/Main/ArduinoBoardMega2560.

[2.] Amitesha Sachdeva, Mahesh Gupta, Manish Pandey, Prabham Khandelwal, Development Of Industrial Automatic Multi Colour Sorting and Counting Machine Using Arduino Nano Microcontroller and TCS3200 Colour Sensor, Department of Mechanical Engineering SRM University, Modinagar Ghaziabad, India. The International Journal of Engineering and Science (IJES), || Volume || 6 || Issue || 4 || Pages || PP 56-59 || 2017 || ISSN e: 2319-1813 ISSN p: 23191805.

[3.] Bambang Priyadi, Aplikasi Sensor Warna Jenis tcs230 Sebagai Alat Penentu Komposisi Warna Pada Cat Mobil, Aplikasi sensor warna tcs230, Hal 47-61.(paper).

[4.] Bindu S Pagad, Namratha D Gaddad. Asst. Prof. Chaitanya K Jambotkar, Arduino Based Color Detection for Visual Impaired, $6^{\text {th }}$ SEM Student in Departemen Of Electrical and Electronics Engineering, K.L.E.I.T, Hubli, Kamataka, India, (C) February 2019 | IJIRT | Volume 5 Issue 9 | ISSN: 2349-6002.

[5.] http://ecadio.com/image/catalog/information/belajar-arduino-mega-2560.jpg.

Diakses pada 20 Agustus 2019.

[6.] http://oipall.blog.st3telkom.ac.id/wp-content/uploads/sites/302/2016/01/Komponen-Utamadalam-Sistem-RFID.jpg. Diakses pada 2 September 2019.

[7.] https://www.robotistan.com/2x16-lcd-screen-white-over-blue-tc1602a-2619-11-B.jpg. Diakses pada 19 September 2019.

http://3.bp.blogspot.com/enQcKT5gy10/VP68Ppxj1mI/AAAAAAAAATc/ziENUK3ZSsQ/s1600/RFID-chip.png.

Diakses pada 2 Oktober 2019.

[8.] Kunhimohammed C.K, Muhammed Saifudeen K.K, Sahna S, Gokul M. S and Shaeez Usman Abdulla, Automatic Color Sorting Machine Using TCS230 Color Sensor And PIC Microcontroller, Dept. of Applited Electronics and Instrumentation M.E.S College of Engineering Kuttipuram Kerala, India. Internsional Journal of Research and Innovations in 
Science and Technologi, Volume 2 : Issue 2 : 2015, ISSN (Online) : 2394-3858, ISSN (Print) : 2394-3866.

[9.] Marlinda Ike Sari, Rini Handayani, Simon Siregar, Bagus Isnu (November 2018), Pemilah Benda Berdasarkan Warna Menggunakan Sensor Warna TCS3200, D3 Teknik Komputer, Fakultas Ilmu Terapan, Universitas Telkom. TELKA, Vol.4 No.2 November 2018, pp. 85-90, ISSN e: 25409123, ISSN p: 2502-1982.

[10.] Nugraha, Charolos Hanung Aji Agung. (2016). Penghitung Laju Menggunakan RFID Berbasis Arduino. Universitas Santa Dharma : Teknik Elektro, Fakultas Sains dan Teknologi, 19 Februari 2016.

[11.] Tushar G. Gaikar, Soham N. Zadokar, Rajendra S, Bhandari (April 2016), Object Sorting Using Color Sensor And Arduino, EXTC Departement University of Mumbai. Internasional Jurnal on Recent and Innovation Trends in Computing and Communication, Volume : 4 Issue : 4, ISSN : 2321-8169, 483-486.

[12.] Tri Rahajoeningroem, Wahyudi. 2013. SISTEM KEAMANAN RUMAH DENGAN MONITORING MENGGUNAKAN JARINGAN TELEPON SELULAR. Teknik Komputer, Universitas Komputer, Universitas Komputer Indonesia. 